\title{
COST-EFFECTIVENESS ANALYSIS OF TYPE 2 DIABETES IN OUTPATIENT THERAPY IN TURKEY
}

\author{
TIP 2 DIYYABETTE AYAKTAN TEDAVIDE MALIYET ETKINLIK ANALIZI \\ Gülden YÜRÜYEN*, Eylem ÖZGÜN ÇiL*, Yücel ARMAN*, Pinar DEMİ**, \\ Ramazan ÇAKMAK**, Tuğçe AKCAN**, Mustafa ÖZCAN*, Murat AKARSU*, \\ Özgür ALTUN*, Şengül AYDIN YOLDEMİ**, Kerem KIRNA***, İlkim Deniz TOPRAK*, \\ Tufan TÜKEK**
}

\begin{abstract}
Objective: The purpose of this study is to estimate the cost-effectiveness of screening, treatment, and examination of patients with type 2 diabetes during a yearly period and expose its importance in diabetes control.

Materials and Methods: Five hundred patients with type 2 diabetes who had received outpatient therapy in the past year were enrolled in the study. Patients were divided into three categories according to their hemoglobin Alc (HbAlc) (\%) levels: good control (HbAlc $<7 \%$ ), fair control ( $\mathrm{HbA} 1 \mathrm{c} 7 \%-10 \%)$, and poor control ( $\mathrm{HbAlc}>10 \%$ ). Average annual costs of treatment, examination, and laboratory workup were compared for the three groups.

Results: The average annual cost of medication for 500 type 2 diabetes patients was $\$ 556.50$, while the cost of screening and examination was $\$ 89.20$ per patient. The average yearly treatment cost per patient was $\$ 287.90$ for patients with $\mathrm{HbA} 1 \mathrm{c}$ $\leq 7 \%, \$ 647.90$ for patients with $\mathrm{HbA1c} 7 \%-10 \%$, and $\$ 752.40$ patients with $\mathrm{HbA1c} \geq 10 \%$. The average annual costs of treatment with only oral anti-diabetic drugs (OAD), insulin only, and both OAD and insulin were $\$ 154.80, \$ 837.50$, and $\$ 819.30$, respectively.

Conclusion: While the cost to treat diabetic patients with good control was significantly lower than the treatment cost of patients with poor control, there was no significant difference in laboratory workup and examination costs. When patients treated with OAD only, insulin only and OAD + insulin were compared, treatment costs for the OAD only group were significantly lower than the costs to treat the insulin only and OAD + insulin groups. No correlation between age or sex and medication cost were found. However, a strong correlation was found between diabetes duration and treatment cost. Keywords: Diabetes mellitus type 2; cost effectiveness; healthcare costs
\end{abstract}

\section{ÖZET}

Amaç: Çalışmamızın amacı; bir yıllık süre içerisinde takip ettiğimiz tip 2 diyabetik hastaların tedavi, tetkik ve muayene için harcanan maliyetlerini ortaya koyup, bu maliyetlerin bir y1llık kontrolde ne kadar etkili olduğunu göstermektir.

Gereç ve Yöntem: Son bir yıl içinde Tip 2 Diyabet tanısı ile polikliniğimizde ayaktan takip edilen 500 hasta çalışmaya alındı. HbA1c (\%) değerlerine göre 'iyi regüle $\leq 7$ ', 'kötü regüle7-10', 'çok kötü regüle $\geq 10$ ' olmak üzere 3 gruba ayrıldı ve üç grubun ortalama yıllık tedavi, muayene ve tahlil maliyetleri hesaplanarak karşılaştırmaları yapıldı.

Date received/Dergiye geldiği tarih: 01.12.2016 - Date accepted/Dergiye kabul edildiği tarihi: 15.08.2017

*İstanbul Okmeydanı Eğitim ve Araştırma Hastanesi, İç Hastalıkları Bölümü

**İstanbul Üniversitesi İstanbul Tıp Fakültesi, İç Hastalıkları Anabilim Dalı

***ístanbul Haseki Eğitim ve Araştırma Hastanesi, İç Hastalıkları Bölümü, İstanbul, Türkiye

(Corresponding author/İletişim kurulacak yazar: ilkimdenizzz@hotmail.com) 


\section{Cost-effectiveness analysis of type 2 diabetes}

Bulgular: Son bir yıldır poliklinikte takip edilen 500 Tip 2 Diyabet tanısı olan hastanın bir yıllık ilaç maliyeti ortalaması kişi başı $1614 \mathrm{TL}$, ortalama muayene ve tahlil maliyeti ise $250 \mathrm{TL}$ olarak hesaplandı. HbAlc $\leq 7$ olan hastalarda bir yılllk ortalama tedavi maliyeti $835 \mathrm{TL}, \mathrm{HbA1c} 7-10$ arasinda olan hastalarda $1879 \mathrm{TL}$ iken, HbA1c $\geq 10$ olan hastalarda ise 2182 TL saptandı. Sadece oral antidiyabetik (OAD) kullanan grubun bir yıllık ortalama ilaç maliyeti 449 TL iken bu değer insülin kullanan grupta: $2429 \mathrm{TL}$ ve OAD+insülin grubunda ise $2376 \mathrm{TL}$ saptandi.

Sonuç: Tedavi maliyetleri açısından değerlendirildiğinde iyi kontrollü diyabetik hastaların tedavi maliyetleri, kötü kontrollü hastalardan anlamlı olarak daha düşük iken, iki grup arasında muayene ve tahlil harcamalarında anlamlı fark saptanmadı. OAD kullanan grup ile insülin ve OAD+insülin kullanan gruplar karşılaştırıldığında, OAD kullanan grubun tedavi maliyeti diğer iki grubun maliyetinden anlamlı olarak düşük tespit edildi. Yaş ve cinsiyet ile diyabet ilaç maliyeti arasında korelasyon yokken, diyabet yaşı ile tedavi maliyeti arasında istatiksel olarak anlamlı korelasyon saptandı.

Anahtar Kelimeler: Tip 2 diabetes mellitus; maliyet etkinlik; tıbbi bakım maliyeti

\section{INTRODUCTION}

Type 2 diabetes mellitus is a systemic and metabolic disorder leading to complications such as blindness, extremity loss, and cardiovascular and renal diseases. The prevalence of diabetes mellitus is increasing worldwide, especially in developing countries. According to the World Health Organization (WHO) the number of people with diabetes will reach 300 million in 2025 (1).

Diabetes imposes a high economic burden on the healthcare system. Patients with diabetes attend outpatient clinics more frequently, use more medications, are more likely to be hospitalized, and have a higher probability of requiring emergency and long-term care (2). The global health expenditure on diabetes was estimated between $\$ 376$ and $\$ 672$ billion in 2010 (2). It is also estimated that expenditures on diabetes accounts for $12 \%$ of the world's spending on health. On average, $\$ 1330.00$ is spent on each person with diabetes. Of these costs, hospitalizations account for the greatest proportion, whereas medication costs for managing the disease are relatively low. Indeed, the costs of oral medications used in glycemic control of type 2 diabetes patients account for only $4 \%$ of total healthcare costs for diabetes (3).

\section{MATERIALS AND METHODS}

The present study is a cross-sectional study enrolling type 2 diabetes mellitus patients who were followed up by a physician in a third-level education and research hospital in İstanbul for at least one year. The study was approved with file number 6718 on 01.02 .2016 by the ethics commitee of Okmeydani Training and Research Hospital. In total, 500 randomly selected patients attending internal medicine outpatient clinics were enrolled in the study. Informed consent forms were obtained from each patient. During their clinical controls, patients were examined by experienced specialists. Their fasting and postprandial blood glucose levels and $\mathrm{HbA} 1 \mathrm{c}$ levels for the past month and all their medications used in the past year were noted.

Data were confirmed by referring to the hospital laboratory data system and the pharmacy database Medulla. Data about all medical drugs, laboratory workup tests, and clinic visits in the past year were collected for cost effectiveness analysis. Patients were divided into three groups according to their $\mathrm{HbA} 1 \mathrm{c}$ levels to determine their levels of glycemic control: The good control group included 157 patients with $\mathrm{HbA} 1 \mathrm{c} \leq 7 \%$. The fair control group comprised $240 \mathrm{pa}-$ tients with $\mathrm{HbAlc}$ between $7 \%$ and $10 \%$. The poor control group was composed of 103 patients with $\mathrm{HbA} 1 \mathrm{c} \geq 10 \%$. The medical costs of the three diabetic groups were analyzed by collecting data about examination, treatment, and laboratory workup costs during a yearly evaluation period.

\section{Statistical Analysis}

Statistical analyses were performed using the program IBM Statistical Package for the Social Sciences (IBM SPSS Statistics, Armonk, NY, USA) version 20. The following data were collected for each patient: age, gender, educational status, and socioeconomic status. Meanwhile, data about yearly total treatment, control, laboratory workup, and hospitalization costs were recorded in SPSS. Patient groups were compared using the "Test for the Significance of the Difference between the Means of Two Independent Samples" (Student's $t$-test or independent samples $t$-test) and "Analysis of Variance" (ANOVA).

\section{RESULTS}

Overall, 500 patients were screened. Of these, $327 \mathrm{pa}-$ tients were female and 173 were male. The mean patient 


\section{Tip 2 diyabette maliyet etkinlik analizi}

age was $57 \pm 10$ years. Diabetes duration, the mean time since diagnosis with type 2 diabetes mellitus, was $9 \pm 7$ years. The socio-demographic characteristics of the patients are listed in Table 1.

The overall prevalence of macro and micro complications of diabetes, such as cardiovascular and renal diseases, retinopathy, neuropathy, and extremity complications, was $46 \%$. Considering the HbAlc levels of the patient groups, the good control group ( $\mathrm{HbAlc}<7 \%$ ) consisted of 157 patients (31.4\%), the fair control group (HbAlc 7-10) consisted of 240 patients (48\%), and the poor control group (HbA1c $>10 \%)$ consisted of 103

Table 1. Socio-demographic characteristics of the patients

\begin{tabular}{lcc} 
& Type 2 diabetic patients \\
Variables & $\mathbf{n}$ & \% \\
Mean Age & \multicolumn{2}{c}{$57 \pm 10$} \\
Gender & \multicolumn{2}{c}{} \\
Female & 327 & 65.4 \\
Male & 173 & 34.6 \\
Educational Level & & \\
Illiterate & 52 & 10.4 \\
Literate only & 53 & 10.6 \\
Primary school graduate & 312 & 62.4 \\
High school graduate & 49 & 9.8 \\
College graduate & 26 & 5.2 \\
Postgraduate degree & 8 & 1.6 \\
Profession & & 81.2 \\
Employed & 94 & 18.8 \\
Unemployed or Retired & 406 & \\
Total & 500 participants \\
\hline n: total number & & \\
\hline
\end{tabular}

patients (20.6\%). Most patients were in the fair control group. The percentage of well-regulated diabetes patients was $31.4 \%$.

Patients were evaluated for the use of pharmacotherapy to treat diabetes. In the good control group, $72 \%$ of patients were taking only OADs, $5 \%$ were taking only insulin, 21\% were taking both OADs and insulin, and $2 \%$ were being treated with diet alone. In the fair control group, $28 \%$ of patients were taking only OADs, $11 \%$ were taking insulin, $60 \%$ were taking OADs and insulin, and $0.4 \%$ were being treated with diet alone. In the poor control group, $12 \%$ of patients were taking only OADs, $8 \%$ were taking insulin, and $80 \%$ were taking OADs and insulin (Table 2). Overall, $62 \%$ of patients were under insulin therapy.

The majorty of patients were obese. The relation between $\mathrm{HbAl}$ c and body mass index (BMI) was shown in Table 3.

The majority of patients in the good control group were undergoing therapy only with oral anti-diabetic drugs, whereas the majority of patients in the fair and poor control groups were treated with a combination of OAD and insulin. Metformin was the most frequently used anti-diabetic drug $(87 \%, n=435)$. Metformin plus an insulin secretagogue was the most frequently used drug combination $(40 \%, \mathrm{n}=176)$, followed by metformin plus dipeptidyl peptidase-4 inhibitors (DDP-4 inh) (28\%, $\mathrm{n}=124$ ). Similarly, metformin was the most frequently used oral anti-diabetic drug, followed by insulin secretagogues (sulfonylurea and glinids) and dipeptidyl peptidase-4 inhibitors (DDP4 inh). The overall usage percentages of insulin secretagogues, pioglitazone, DDP-4 inhibitors, and acarbose were $37.4 \%, 12.2 \%, 26.4 \%$, and $2.8 \%$, respectively. Insulin usage percentages for long-acting, short-acting, and mixed-activity insulin were $44.4 \%, 29.8 \%$, and $20.4 \%$, respectively.

When physicians' follow-ups were evaluated in a yearly period, it was noted that $83 \%$ of patients were seen by family practitioners. The remaining $17 \%(n=90)$ of patients were seen only by specialists working in train-

Table 2. Pharmacotherapy for diabetes according to HbA1c levels

$\begin{array}{lcccc}\text { HbA1c (\%) } & \text { OAD only (n) } & \text { Insulin only (n) } & \text { OAD and insulin (n) } & \text { Without therapy (n) } \\ \leq 7 \text { (Good control) } & 113 & 8 & 33 & 3 \\ 7-10 \text { (Fair control) } & 68 & 27 & 144 & 1 \\ \geq 10 \text { (Poor control) } & 13 & 8 & 82 & 0 \\ \text { Total } & 194 & 43 & 259 & 4\end{array}$

OAD: oral antidiabetic; n: total number; HbA1c: Hemoglobin A1c 


\section{Cost-effectiveness analysis of type 2 diabetes}

ing and research hospitals. In all, $83 \%$ of patients were seen by both family practitioners and internal medicine specialists. In general, $14 \%$ of patients attended internal medicine clinics at least four times in a one-year period (Table 4).

Average yearly diabetes expenditures estimated for patient groups are listed in Table 5.

A significant correlation was found between $\mathrm{HbAlc}$ levels and medication costs. We found that patients with increased $\mathrm{HbAlc}$ levels and unregulated diabetes spent more on medications than those with $\mathrm{HbAlc}$ in the normal range and those with well-controlled diabetes. No correlation was found between examination and laboratory workup costs and $\mathrm{HbAlc}$ levels. When diabetes expenditures and diabetes duration were analyzed, a significant correlation was found.

\section{DISCUSSION}

For the first time, this study reports average annual diabetes expenditures for type 2 diabetic patients followed up by specialists in a tertiary level hospital and correlates diabetes regulation via $\mathrm{HbAlc}$ levels and expenditures in Turkey. Although expenditures for diabetes complications are much higher than the annual average medication expenditure, it is important to note that medication expenditures are as important as complication expenditures when early disease diagnosis, an efficient follow-up process, and prevention of disease complications are considered.

Regular patient follow-up and patients' accessibility to physicians and medications are the most important concerns of healthcare authorities for type

Table 3. Relation between HbA1c and body mass index (BMI)

\begin{tabular}{|lccc|}
\hline HbA1c $(\%)$ & $\begin{array}{c}\leq 7 \text { (Good } \\
\text { control) }\end{array}$ & $\begin{array}{c}\mathbf{7 - 1 0}(\text { Fair } \\
\text { control) }\end{array}$ & $\begin{array}{c}\mathbf{2 1 0} \text { (Poor } \\
\text { control) }\end{array}$ \\
\hline BMI & $\begin{array}{c}29 \\
(\mathrm{n}=157)\end{array}$ & $32(\mathrm{n}=240)$ & $32(\mathrm{n}=103)$ \\
\hline
\end{tabular}

HbA1c: Hemoglobin A1c; BMI: body mass index
Table 4. Data about diabetes follow-up, training for diabetes, and patients' physical exercise (Includes data for a recent one-year period. Laboratory workups of blood tests were applied in every clinic visit)

\begin{tabular}{|c|c|c|c|c|}
\hline \multicolumn{2}{|l|}{ Hba1c (\%) } & $\begin{array}{c}\leq 7 \\
\text { (Good } \\
\text { control) }\end{array}$ & $\begin{array}{c}\text { 7-10 } \\
\text { (Fair } \\
\text { control) }\end{array}$ & $\begin{array}{c}\geq 10 \\
\text { (Poor } \\
\text { control) }\end{array}$ \\
\hline \multicolumn{2}{|l|}{$\begin{array}{l}\text { Trained for } \\
\text { diabetes } \\
(n=106)\end{array}$} & 31 & 55 & 20 \\
\hline \multicolumn{2}{|l|}{$\begin{array}{l}\text { Non-trained } \\
\text { for diabetes } \\
(n=394)\end{array}$} & 126 & 185 & 83 \\
\hline \multicolumn{2}{|l|}{$\begin{array}{l}\text { Regular } \\
\text { physical } \\
\text { exercise } \\
(n=109)\end{array}$} & 42 & 46 & 21 \\
\hline \multicolumn{2}{|l|}{$\begin{array}{l}\text { Non- regular } \\
\text { physical } \\
\text { exercise } \\
(n=391)\end{array}$} & 115 & 184 & 82 \\
\hline \multirow{4}{*}{$\begin{array}{l}\text { Family } \\
\text { practitioner } \\
\text { attendance } \\
(\mathrm{n}=500)\end{array}$} & None & 90 & & \\
\hline & Once in a year & 24 & & \\
\hline & $\begin{array}{l}2 \text { times in a } \\
\text { year }\end{array}$ & 69 & & \\
\hline & $\begin{array}{l}3 \text { or more } \\
\text { times in a } \\
\text { year }\end{array}$ & 377 & & \\
\hline \multirow{4}{*}{$\begin{array}{l}\text { Internal } \\
\text { medicine } \\
\text { specialist } \\
\text { attendance } \\
(\mathrm{n}=500)\end{array}$} & Once in a year & 197 & & \\
\hline & $\begin{array}{l}2 \text { times in a } \\
\text { year }\end{array}$ & 127 & & \\
\hline & $\begin{array}{l}3 \text { times in a } \\
\text { year }\end{array}$ & 106 & & \\
\hline & $\begin{array}{l}4 \text { or more } \\
\text { times in a } \\
\text { year }\end{array}$ & 70 & & \\
\hline
\end{tabular}

HbA1c: Hemoglobin A1c; n: total number

Table 5. Relation between HbA1c and diabetes expenditures

\begin{tabular}{|lcc|} 
HbA1c (\%) & $\begin{array}{c}\text { Average medication costs, USD } \\
\text { (Annual) }\end{array}$ & $\begin{array}{c}\text { Average examination and laboratory } \\
\text { workup costs, USD (Annual) }\end{array}$ \\
\hline 7 (Good control) & 287.93 & 84.82 \\
$7-10$ (Fair control) & 647.90 & 87.58 \\
$\geq 10$ (Poor control) & 752.41 & 84.82 \\
\hline
\end{tabular}

HbA1c: Hemoglobin A1c; USD: United states dollar; n: total number 


\section{Tip 2 diyabette maliyet etkinlik analizi}

2 diabetic patients. According to our data, patients have no problem attending hospitals and receiving medications and can easily attend different healthcare institutions at will. However, $14 \%$ of the patient population attends clinics more than four times in a year. Also, assessment of $\mathrm{HbAlc}$ levels revealed that the diabetes regulation ratio is below the desired level (patients with $\mathrm{HbAl} 1 \mathrm{c}<7 \%$ accounted for $31 \%$ of the study group). Similarly, in 2010 Satman et al. (4) and the TURDEP-II (Turkish Diabetes Epidemiology Study) group showed that the glycemic control ratio was below the desired level for diabetic patients. TURDEP-II found that only $35.48 \%$ of diabetic patients' HbA1c levels were below $6.5 \%$.

Most of the patients in the fair and poor control groups were females and obese individuals. This may be explained by insufficient physical exercise and non-adherence to diet suggestions. The overall frequency of regular physical exercise was $25 \%$ among participants. According to our findings, the patients in the poorly controlled group consisted mostly of patients with non-regular physical exercise. Furthermore, we revealed that the majority of patients did not obtain education about diabetes in the past year. We suggest that efficient education of patients about diabetes may have a positive impact on cost-effective control of the disease.

The prevalence of type 2 diabetes mellitus is increasing considerably. If we consider the increased average lifespan and urbanization and examine the problem from a public health perspective, type 2 diabetes mellitus may cause an unexpected increase in health expenditures. In our study, we assessed the success of treatment according to direct expenditures of diabetes such as treatment, follow-up, and laboratory workup costs. However, we know that there are some indirect expenditures such as workforce loss, reduced quality of life, depression, and time and money spent by relatives on the care of diabetic patients.

The present study has shown that treatment becomes more difficult, and medical expenditures increase with increased diabetes duration. Moreover, we revealed that cost-effective treatment with only oral anti-diabetic drugs can be achieved with patients who are doing regular physical exercise and following diet suggestions. We also found that insulin usage increases expenditures. Consequently, the results of this study reveal that training patients about diabetes and carbohydrate counting is a valuable strategy. Additionally, physicians should avoid overuse of insulin and should individualize insulin treatment.
The International Diabetes Federation (IDF) reported both national and global medical costs of diabetes in the $3^{\text {rd }}$ edition of the Diabetes Atlas in 2006 and updated the report in 2010. In the updated report, greater than average medical expenditures per patient were found due to the increased world population and diabetes prevalence (2). Additionally, diabetes complications and the costs of these complications are two important subjects which have been studied previously. It is a known fact that efficient diabetes treatment decreases diabetes complications and their costs. Ineffective treatment regimens cause complications and therefore increase the cost associated with diabetes. These facts increase the significance of our present study.

Previously, Malhan et al. (6) conducted the largest cost effectiveness analysis of diabetes treatment in Turkey and exposed the total cost of diabetic complications. The total costs of complications of type 2 diabetes were estimated at between $\$ 3.93$ and $\$ 4.44$ billion and accounted for $1 \%$ of the gross domestic product (GDP).

Preventing diabetes and developing efficient treatment and screening strategies will prevent diabetic complications and increase the control of medical expenditures. Our study reveals the cost of the disease control process and provides important knowledge about where we stand with regard to cost effectiveness.

\section{CONCLUSION}

Type 2 diabetes mellitus is a common metabolic disease and plays an important role in both national health systems and the world economy. At present, it cannot be stated that this disease is being controlled in a cost-effective way. To prevent and control the disease, effective measures should be determined throughout the country and the world, and concrete steps should be taken starting at the individual level.

Antalya'da düzenlenmiş olan 17. Ulusal İç Hastalıkları Kogresi'nde poster sunumu olarak 2015 yllinda sunulmuștur.

\section{REFERENCES}

1. King H, Rewers M. Global estimates for prevalence of diabetes mellitus and imparied glucose tolerance in adults. WHO Ad Hoc Diabetes Reporting Group. Diabetes Care 1993;16(1):157-77. [CrossRef]

2. Zhang P, Zhang X, Brown J, Vistisen D, Sicree R, Shaw J, et al. Diabetes Atlas- Global health care expenditure on diabetes for 2010 and 2030. Diabetes Res Clin Pract 2010;87(3):293-301. [CrossRef] 
3. Jönsson B. Revealing the cost of Type 2 diabetes in Europe. Diabetologia 2002;45(7):S5-12.

4. Satman I, Omer B, Tutuncu Y, Kalaca S, Gedik S, Dinccag N, et al. TURDEP-II Study Group. Twelveyear trends in the prevalence and risk factors of diabetes and prediabetes in Turkish adults. Eur J Epidemiol 2013;28(2):169-80. [CrossRef]
5. International Diabetes Federation, Diabetes Atlas, İnternational Diabetes Federation, Brussels, 3rd ed., 2006.

6. Malhan S, Öksüz E, Babineaux MS, Ertekin A, Palmer PJ. Assessment of the direct medical costs of the type 2 diabetes mellitus and its complications in Turkey. Turk J Endocrinol Metab 2014;18(2):3943. [CrossRef] 